\title{
Geochemical, MCX and neutron diffraction in situ analyses of high OH blue topaz, Padre Paraíso (BR)
}

Nicola PreCisvalle ${ }^{1 *}$, ANNALisa MARTUCCI ${ }^{1}$, COSTANZA BONADIMAN ${ }^{1}$, THOMAS HANSEN ${ }^{2}$, LARA GIGLI $^{3}$, JASPER Plaisier ${ }^{3}$, AUgusto NOBRE G. ${ }^{4}$

${ }^{1}$ University of Ferrara, Physics and Earth Sciences, Via Saragat 1, 44122 Ferrara, Italy (*correspondence: prcncl@unife.it)

${ }^{2}$ Institut Laue-Langevin (ILL4-138), 71 avenue des Martyrs, 38000 Grenoble, France

${ }^{3}$ Elettra - Sincrotrone Trieste, ss 14, km 163.5, 34149 Basovizza, Trieste Italy.

${ }^{4}$ Geosciences Institute, University of São Paulo Rua do Lago, 562 - Butantã, São Paulo, 05508-080, Brazil.

The aim of this work is to deeply investigate the role of $\mathrm{OH} / \mathrm{F}$ substitution in topaz. We focused on the crystal structure and crystal chemistry of natural $(\mathrm{OH}, \mathrm{F})$-topazes occurring in Padre Paraíso municipality (PadPar), Minas Gerais State (Brazil) combining the potentiality of both synchrotron and neutron facilities. Solid and biphasic inclusions have been observed as well as a high R.I. Temperature-dependent variation of the unit cell parameters upon heating were set in the $298-1300 \mathrm{~K}$ temperature range. On the basis of the neutron diffraction data, the F-amount gives rise to $\sim 1.03$ a.p.f.u. so the chemical composition can be inferred as $\mathrm{Al}_{1.92} \mathrm{Si}_{0.96} \mathrm{O}_{4} \mathrm{~F}_{1.032} \mathrm{OH}_{0.968}(\mathrm{OH} /(\mathrm{OH}+\mathrm{F})=0.484)$. The fluorine content $(10.94 \% \mathrm{wt})$ appears to be in very good agreement with that measured by means of SEM-EDAX $(9.98 \% \mathrm{wt})$. Unit-cell parameters increase at increasing temperature (up to $1010 \mathrm{~K}$ ), indicating that the thermal expansion is the dominant mechanism at this stage of the experiment. Above this temperature, this trend suddenly changes as result of the structural modifications induced by the fluorine departure. A rapid decomposition of the the main diffraction peaks associated with the topaz is reported at $1181^{\circ} \mathrm{K}$ and a second phase appeared to grow. This reveals the topaz transformation in mullite. At $1272^{\circ} \mathrm{K}$ Rietveld refinement indicated $\sim 30$ and $70 \%$ in weight of topaz and mullite, respectively. At the same time, the fluorine content goes from 0.768 to 0.63 a.p.f.u The fluorine fugacity [expressed as the ratio $\log (\mathrm{fH} 2 \mathrm{O} / \mathrm{fHF})]$ of possible fluids (or $\mathrm{H}_{2} \mathrm{O}-\mathrm{F}$ saturated silic melt) indicated that PadPar topaz was stabilized by $\mathrm{H}_{2} \mathrm{O}$ saturated fluids- a $\mathrm{H} 2 \mathrm{O}$ saturated peraluminous, low-Ca compositions melt/fluid(s) with $\mathrm{F}$ contents not exceeding $1 \mathrm{wt} \%$ [1].

[1] Lukkari et al.(2007) Contrib. Mineral. Petrol., 153, 273288 